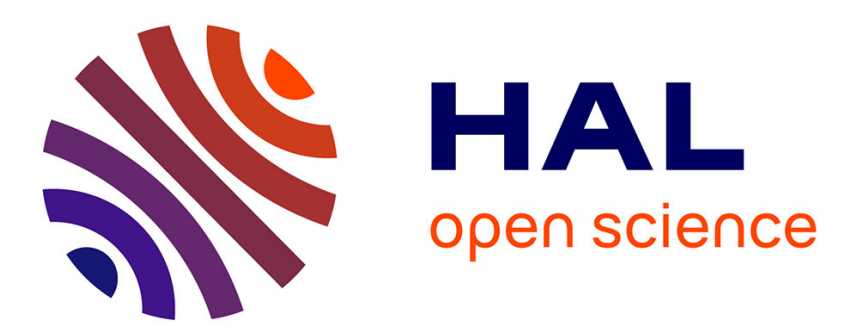

\title{
Making the right move: how families are using transfers to adapt to socio-spatial differentiation of schools in the greater Paris region
}

Jean-Christophe François, Franck Poupeau

\section{- To cite this version:}

Jean-Christophe François, Franck Poupeau. Making the right move: how families are using transfers to adapt to socio-spatial differentiation of schools in the greater Paris region. journal of educational policy, 2007, 22 (1), pp.31 - 47. 10.1080/02680930601065858 . halshs-00160786

\section{HAL Id: halshs-00160786 \\ https://shs.hal.science/halshs-00160786}

Submitted on 18 Jul 2007

HAL is a multi-disciplinary open access archive for the deposit and dissemination of scientific research documents, whether they are published or not. The documents may come from teaching and research institutions in France or abroad, or from public or private research centers.
L'archive ouverte pluridisciplinaire HAL, est destinée au dépôt et à la diffusion de documents scientifiques de niveau recherche, publiés ou non, émanant des établissements d'enseignement et de recherche français ou étrangers, des laboratoires publics ou privés. 


\title{
MAKING THE RIGHT MOVE
}

How families are using transfers to adapt to sociospatial differentiation of schools in the greater Paris region

\begin{abstract}
"To account more fully for the differences in life-style between the different fractions especially as regards culture - one would have to take account of their distribution in a socially ranked geographical space. A group's chances of appropriating any given class of rare assets (as measured by the mathematical probability of access) depend partly on its capacity for the specific appropriation, defined by the economic, cultural and social capital it can deploy in order to appropriate materially or symbolically the assets in question, that is, its position in social space, and partly on the relation between its distribution in geographical space and the distribution of the scarce assets in that space. (That relationship can be measured in average distances from goods or facilities, or in travelling time, which involves access to private or public transport). In other words, a group's real social distance from certain assets must integrate the geographical distance, which itself depends on the group's spatial distribution and, more precisely, its distribution with respect to the 'focal point' of economic and cultural values, i.e., Paris or the major regional centres..."

(Pierre Bourdieu, Distinction, London \& New York, Routledge \& Kegan Paul, 1984, translated by Richard Nice, p.124).
\end{abstract}

Since the late 1980s, much research has been devoted to the strategies that families use in France to avoid sending their children to the public schools assigned to them by the carte scolaire, which defines school districts. To analyse trends and student movement in education, sociologists use the four categories established by the French Ministry of Education to identify and group the professional status of parents. ${ }^{1}$ No doubt, every attempt at classification must allow for some degree of approximation [MERLLIE, 1990]. However, it is worthwhile asking here if these categories are appropriate for analysing individual approaches to schooling, which are increasingly difficult to comprehend due to recent transformations of the education system in France. Indeed, since the 1970s, policy has been aimed at developing mass education and formally unifying previously separate educational paths, making the differences between various courses of study less and less visible, and contributing to a confusion of educational itineraries [CONVERT, 2003].

The purpose of this article is to examine the social factors that influence different individual choices with regard to schooling in France [see Box 1], and aims to go far

\footnotetext{
${ }^{1}$ Privileged (A and B), middle class, underprivileged
} 
beyond a simple incantatory reaffirmation of the importance of social origin. We set out with relatively well-established empirical facts: middle-class families, who live in working-class communities/towns, can (if they have the means) avoid sending their children to the assigned public school in their district by requesting a transfer to another public school, or choosing a private school; they can also massively enrol their children in the assigned public school of their district [VAN ZANTEN, 2001; POUPEAU, 2004].

In some "isolated" communities, where schools rarely exchange students with neighbouring towns (e.g. geographic or administrative barriers, lack of transport), middle-class families, who are particularly dependent on educational achievement to preserve their social status, tend to develop collective strategies for intervening in the life of the schools that their children attend. On the other hand, middle-class families who live in a more permeable and open residential and educational context have a wider range of options at their disposal. Thus, belonging to the same social category does not have much significance in educational spaces that are different due to accessibility, school hierarchy, and the resources that families can mobilise [FRANÇOIS \& POUPEAU, 2005]. While there is substantial sociological research and literature on the different criteria that families use to choose a school for their children, relatively little has been said so far about how the geographic location of the school and its implantation in a given space influence these choices.

In a study on how families choose a "good school", Robert Ballion analysed requests for school transfers at Grade 6 and showed that since the 1980s the relative free choice that families have in selecting schools for their children has led to a ranking of schools based on their location, their social composition and the characteristics of their students [BALLION, 1986]. In addition to evaluating schools according to their positive or negative reputation, families have more "functional" reasons for choosing a particular school, such as its proximity to the home. The relationship between spatial and social variables was highlighted in Ballion study for one important reason: it showed that school transfers and the changes they provoked in school enrolment have increased social inequalities in educational opportunities in the sense that the most privileged families were also those whose requests for transfers were most often satisfied. Yet, the belief that privileged families succeed in getting their school transfer requests approved more often 
than other families cannot always be verified at the local level. For instance in Paris, due to procedures implemented at the "academies" (large school districts) level, the social status of families who want to transfer their children to public schools other than the ones assigned to them, does not greatly influence their chances of having their requests fulfilled. Social selection exists nonetheless, but it occurs upstream, early on in the education process, when different social categories - depending on the options offered to them at the local level - manifest an unequal propensity for avoiding the public school of their district [FRANÇOIS, 2002].

In order to examine the specific effects that the spatial aspect (location) of the education offer has on differentiating education practices within the same social category, it seems necessary to understand first of all how school enrolment practices are adapted to different contexts. Too often sociologists tend to consider the factor of social origin alone, or focus on a simple correlation of variables, such as the educational level or income level of parents. However, as Pierre Bourdieu has shown, it is above all a comprehension of the distribution structure of economic and cultural capital that makes it possible to understand the differentiation in schooling practices [BOURDIEU, 1982, 1989]. This article explores the hypothesis that education strategies can only be really understood if one analyses how families - depending on the economic and cultural capital they possess (individually and collectively) - can adapt their strategies to an education offer that has specific socio-spatial characteristics. So, this is essentially a matter of putting the practice of choosing a school together with other social practices, such as cultural practices, but also with "ordinary" practices, linked to where one lives, which often condition the physical access one has to cultural and educational assets.

This article presents the results of a survey that was conducted in a town selected for its exemplary characteristics. It is part of a larger study carried out on a regional scale - Ile-de-France - to examine the growing phenomenon of school transfers. Indeed, the town of Levallois offers many opportunities for different schooling practices, due both to its geographical location and well-established school system [RHEIN et al., 1999]. Furthermore, Levallois is an attractive place to live not only because of the local housing offer, but also because of the access it provides to a large variety of cultural assets that are concentrated in the neighbouring cities of Neuilly and Paris. The questionnaire that 
we distributed to parents of students entering Grade 6 in Levallois thus made it possible to test the hypothesis of how families adjust to the education offer, depending on the distribution of the capital (economic and cultural) they possess.

\begin{abstract}
[BOX 1]
Rejecting the neighbourhood school: the escape from the carte scolaire in France

One of the least know aspects of the French educational system (primary and secondary level) is the practice of assigning pupils to schools in specific districts according to where they live. This districting is defined by the carte scolaire, which is based on an administrative distribution of public schools implemented some 40 years ago to harmonise the country's educational needs with the capacity of its schools. Little by little, however, this became a tool to manage increasing school enrolments due to an education policy of the 1960s that sought to prolong schooling. It also became an avowed means for ensuring maximum social heterogeneity within schools.

The official purpose of the carte scolaire is to impede social segregation between the first cycle of the lycée, which recruits essentially from upper social categories, and the collège (general education), whose enrolment is more working class. In spite of affirmative action measures that were introduced in certain priority zones, disparities between schools have become increasingly evident since the 1980s. This was largely the result of the growing autonomy given to schools, the implementation of decentralisation measures, and the development of a true "education market", in which family strategies for selecting schools are playing an ever greater role.

School enrolment, as intended by the carte scolaire, has been circumvented by two types of practices: the selection of a private school, or of another public school outside the designated district, which requires official dispensation. Many families have thus transferred their children out of the public school of their district, either because they are dissatisfied with the administrative districting or because they cannot accept social heterogeneity in school. Taken together, these school transfers - or évitement scolaire, as the practice is known in France - represent an effort on the part of families to avoid sending their children to the public schools assigned to them by reason of where they live. Besides increasing social inequity between segregated schools, these practices can lead to a biased evaluation of a school's achievement levels and examination results, since students who were initially educated in one school system may receive their diploma in another: a wellknown example is the transfer of pupils from the banlieue (suburbs) to Paris intra-muros.
\end{abstract}

\title{
Levallois: an attractive town
}

Levallois, which used to be an industrial city, is situated in the affluent western part of the Paris region, between very bourgeois Neuilly-sur-Seine and working-class Clichyla-Garenne. Since the 1980s, Levallois has experienced a rapid development of the service sector. This has been accompanied by a process of gentrification, accelerated by a voluntarist local policy of building rehabilitation, affecting half of the town's housing stock. Today, Levallois seems much removed from its working-class past. Since 1983, candidates from various factions of the political right have regularly won municipal 
elections there, and promoted major urban projects in order to attract service industries and middle and upper middle class households. Over the last thirty years, these structural transformations of Levallois - de-industrialisation, development of the service sector and rehabilitation of housing - have changed the social composition of its neighbourhoods.

Situated halfway between the Paris metropolitan region's wealthy western sector and its more working-class northern sector, Levallois has now become an 'attractive' place to live and work for the region's upper middle classes. After experiencing a significant demographic decline between 1946 and 1990 (from 62000 inhabitants to 48000 inhabitants), Levallois' population grew to 55000 in 1999, accompanied by substantial morphological change: with the decrease of blue-collar workers, there was a corresponding increase of white-collar workers and, to a lesser degree, of intermediary professions.

Table A: Evolution of socio-professional categories in Levallois (1990-1999), in percent

Profession

Artisans/shopkeepers

Managers/White collar

professionals

Intermediary professions

Employees

Workers (blue collar)

Unemployed
1990

6.6

22.4

21.8

28.3

20

8.5

\section{9}

24.6

9.2

Very generally, Levallois can be seen as having two main parts: the 'affluent southwestern part (Front de Seine, Villiers Danton, Villiers Michel, Hôtel de Ville and Wilson Rivay districts), which is close to Neuilly and home to mostly white-collar professionals and intermediary professions; and the northeastern part (Maurice Ravel and Trézel, Front de Seine-Ile de la Jatte, and Eiffel districts), which is more working class and borders on Clichy. Despite the persistence of these two contrasting parts, it is evident that privileged social categories are becoming more prominent in all neighbourhoods of 
Levallois, with the exception of the Eiffel district, where half the workers are either blue collar or employees. ${ }^{2}$ Levallois is thus experiencing a process of upward social homogenisation, but this change is not occurring with the same rhythm or intensity throughout the city's different districts. The development of new residential neighbourhoods has led to an increase and diversification of the education offer throughout Levallois. There are 11 nursery schools, 9 public primary schools, 2 private schools (a nursery and a primary school), two public collèges, 1 private collège, 1 public lycée and a private lycée. Levallois also offers special courses for non-French speaking first arrivals and for students who have great learning difficulties or disabilities.

The fact that there are private schools in Levallois and that student registration is flexible (i.e. parents can enrol their children where they choose), has created a situation where the town's primary schools differ considerably with regard to their attractiveness, even within the same neighbourhood. Accessibility to private schools no doubt plays a role in this phenomenon, but an explanation can be found above all in the proximity of the schools from neighbouring towns. Indeed, the schooling of children in Levallois reveals that, from the primary level onward, the trend in school transfers largely goes beyond the city's limits. The main destination is Neuilly-sur-Seine, much more than Paris and, to an even lesser degree, Courbevoie. A comparison of the populations living in the different neighbourhoods of Neuilly and the number of out-of-town pupils who are being schooled in Neuilly, reveals the extent of the phenomenon. Children who do not live in Neuilly are no longer accepted in its schools as they are full, with an average of 28 children per class at the primary level. Two schools in Neuilly have nevertheless increased the number of classes so that they can take in children from other towns. One private school in Neuilly is educating children from Levallois and some from Clichy, while another is accepting children from all neighbouring towns. The demand for out-oftown school transfers comes mostly from Clichy, Paris, Asnières or Courbevoie, and the geographic distribution of this demand is directly linked to how accessible the transfer school is from the town of origin.

\footnotetext{
${ }^{2}$ As a vast renovation programme got underway in this district in 2004 , it is very probable that the "popular" character of the Eiffel neighbourhood has diminished considerably since then.
} 
Children in Levallois can thus move freely from one educational space to another, and have the possibility to pursue separate educational itineraries. This mobility increases at the collège level (grades 6-8). The presence of a private collège that can take in 600 pupils explains why more than $43 \%$ of the in-school children in Levallois are transfers, even though fewer than $3 \%$ have requested a transfer to a public school other than the one in their district. School registration in Levallois was reorganised in 2000 to better balance enrolment in the town's 2 public colleges and the social profiles of their students. The college that is closest to Neuilly has again become the attractive school it was in the 1980s, while the school that is closest to Clichy has become particularly attractive for students from that town. The private college in Levallois is recruiting mostly in Levallois (70\% of its students) and in Clichy. Interviews conducted with the principals of the three collèges in Levallois stress that the flight of students to Paris or Neuilly becomes particularly apparent at the stage when they are registering to enter the lycée, and concerns about one student in ten.

'Now we're giving less preferential treatment than some time ago. Today it's not so much official dispensations and transfers that are an issue, but school flight, which affects some $10-12 \%$ of the students (...) Well-to-do parents in Levallois are increasingly requesting transfers so that they can enrol their children in Neuilly. One college in Levallois is receiving requests for transfers from residents in Clichy or Asnières. In general, however, we reject all of these requests, including those for registering students in Neuilly (...) For transfers between schools in Levallois, we're trying to balance arrivals and departures. When it's a question of school proximity to the home, we never refuse. We're managing this case by case. [Also, when enrolment is high], we let those who want to transfer out of our school system leave. Most of the requests concern transfers to private colleges in Neuilly."

(Head of a college in Levallois)

By now it is well known how competition affects the education offer. Schools in Levallois are implementing strategies to improve their image in the eyes of parents in the hope of attracting families whose social and educational characteristics are likely to increase their children's success in school. The two public colleges, in addition to offering European sections, propose advanced computer and plastic arts workshops. The attractiveness of the schools also includes aspects concerning the building itself, security and safety, and the quality of supervision. Each school is thus trying to emphasise its advantages and promote its assets. As for the private collège, it offers varied extracurricular activities (catechism, theatre, fine arts) and flexible timetables to allow 
students to take up these activities during the school day. The various options that the schools offer should not be seen, however, as sufficient criteria for differentiating the schools. As would be expected, the schools that attract students with a good academic level and privileged family background are those that offer the most "prestigious" courses of study and options (in this case, European sections). Yet, offering prestigious courses of study and options is not enough to improve the negative image of a school, since the "value" of the courses and options offered is closely linked to the quality of the students who are taking them. This point is illustrated by the relatively weak attractiveness of the collège in Levallois situated near Neuilly compared to the schools in Neuilly.

In order to understand what drives student placement in Levallois, it is necessary to go beyond the frameworks set by administrative districting and take a close look at the local system through which Levallois' schoolchildren pass. This means situating ourselves at the local level, within a configuration made up of not only Levallois' schools, but also those of Clichy and Neuilly.

\section{Beyond Levallois: a survey of neighbouring and competing schools}

As has been noted, two important dimensions characterise Levallois' educational space: first of all, its geographical proximity to neighbouring towns (Neuilly, Clichy), which facilitates student mobility among the towns' schools; and, second, the massive presence of private schools in the towns being studied here $(1 / 3$ of the schools in Levallois and Neuilly). When devising educational strategies, families in Levallois can thus consider possibilities that go beyond their city's limits and choose options offered by competing establishments in an enlarged educational space that includes Levallois' neighbouring towns. The notion of "educational itineraries" makes it possible to discuss/identify different educational trajectories at a level that is pertinent to the schools being considered here [Ball et al., 1995; Broccolichi \& van Zanten, 1997].

Our questionnaire was distributed by teachers to all $6^{\text {th }}$ grade students in all of the public and four of the private ${ }^{3}$ collèges in Clichy, Levallois and Neuilly $(\mathrm{n}=2025)$. The global response rate is above $67 \%$. Of the 1370 pupils who answered the questionnaire, 1039

\footnotetext{
${ }^{3}$ Only one of the private collèges refused to distribute the questionnaire.
} 
live in the town where they go to school, and almost $24 \%$ live in a neighbouring town (i.e. in one of the other towns of the survey), but also in Paris, Asnières, Nanterre, Colombes, Courbevoie and Puteaux. The massive presence of private schools explains a transfer rate exceeding $40 \%$ in this zone: $37 \%$ of the pupils are enrolled in private schools (mostly in Neuilly) and 4\% have transferred to another public school. Since more than half of the local education offer (and a major part of the local private education offer) is proposed by Neuilly, half of the students participating in the survey go to school there and $56 \%$ are confirmed transfers (51\% to private schools and $5 \%$ to other public schools). Neuilly polarises most of the school transfers in the Neuilly-Levallois-Clichy zone, with $75 \%$ of transfer students enrolled in its private schools and $63 \%$ in its public schools. In contrast, Clichy seems to have the opposite, repellent effect with regard to school enrolment and transfers. Lacking private schools, Clichy is experiencing "negative educational migration": for every pupil who enters its school system, five leave it. Few of Clichy's schoolchildren are public school transfers and almost all live in town. Levallois' situation is intermediary. If Levallois is considered to be an attractive place to live, it is mostly because of its private schools. More pupils leave its public school system than enter it, and the rate of internal public school transfers is low (3\%). Two migratory movements can be observed here: the arrival of pupils who live in towns in the northern part of the department (Hauts-de-Seine) and the departure of Levallois pupils for private schools in Neuilly.

If Clichy's two colleges are close to Levallois - only two streets away - there is a strong morphological discontinuity between them: the possibilities for passage between Clichy and Levallois are very limited, with few inhabited streets, and a major roadway and railway tracing the border that separates the two towns. On the other hand, for pupils in Levallois, the schools in Neuilly are more accessible, including on foot (except for one school which is at the other end of Neuilly, near the Bois de Boulogne). In addition, pupils from neighbouring towns such as Asnières and Courbevoie are enrolled in schools in Levallois and Neuilly. The college in Levallois located close to Clichy is also the school that is most affected by student transfers, in particular to private schools (18 out of 68 sixth-grade pupils). For a long time this school has had a poor reputation, but it is beginning to improve; now it has enrolled ten pupils from other towns. At the collège 
close to Neuilly, the sports section is drawing pupils from Clichy. As for Neuilly, children can do their entire schooling in private schools there, from primary level up to the lycée.

Table B Questionnaire on schooling practices

\begin{tabular}{|l|c|c|c|}
\hline & $\begin{array}{c}\text { COLLĖGES DE } \\
\text { CLICHY }\end{array}$ & $\begin{array}{c}\text { COLLÈGES DE } \\
\text { LEV ALLOIS }\end{array}$ & $\begin{array}{c}\text { COLLÈGES DE } \\
\text { NEULLY }\end{array}$ \\
\hline Pupils (participating in the survey) & $\mathbf{3 0 6}$ & $\mathbf{3 2 9}$ & $\mathbf{7 3 5}$ \\
\hline Pupils going to school in their district & $\mathbf{2 9 6}$ & $\mathbf{1 8 5}$ & $\mathbf{3 2 4}$ \\
\hline $\begin{array}{l}\text { Nb d'élèves extérieurs scolarisés dans la } \\
\text { commune (dérogations/privé) }\end{array}$ & $\mathbf{4 ( 4 / 0 )}$ & $43(3 / 40)$ & $\mathbf{2 8 2}(\mathbf{2 5 / 2 5 7 )}$ \\
\hline $\begin{array}{l}\text { Pupils from another town enrolled in school } \\
\text { (public/private transfers) }\end{array}$ & $\mathbf{6 ( 6 / 0 )}$ & $\mathbf{1 0 1}(\mathbf{7 / 9 4})$ & $\mathbf{1 2 9}(\mathbf{9 / 1 2 0})$ \\
\hline $\begin{array}{l}\text { Pupils enrolled in school outside the town } \\
\text { where they live (public/private transfers) }\end{array}$ & $\mathbf{1 9 ( 1 / 1 8 )}$ & $\mathbf{5 3 ( 6 / 4 7 )}$ & $\mathbf{3 ( 0 / 3 )}$ \\
\hline Ratio of public/private pupils & $\mathbf{3 0 6 / 0}$ & $\mathbf{1 9 5 / 1 3 4}$ & $\mathbf{3 5 8 / 3 7 7}$ \\
\hline
\end{tabular}

Table C Socio-professional and educational level of families surveyed in the schools

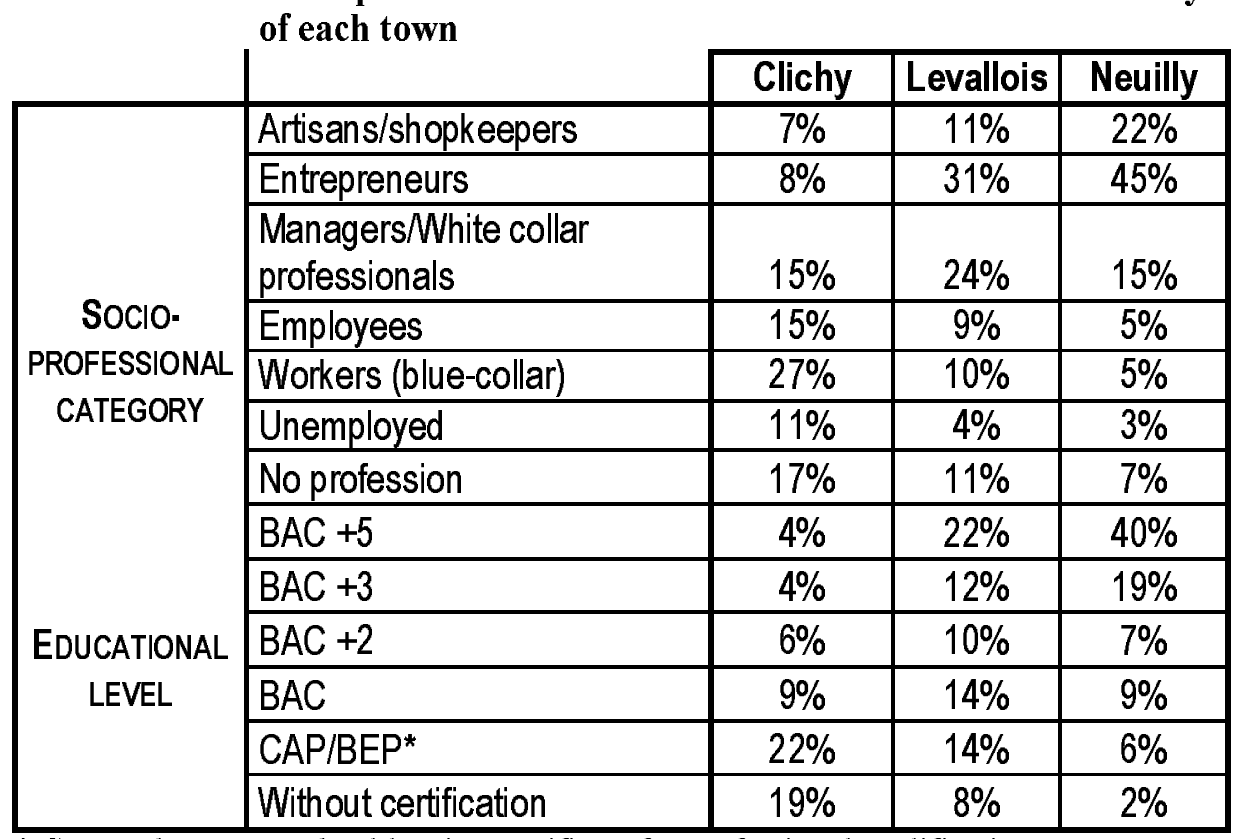

$* \mathrm{CAP}$ and $\mathrm{BEP}$ are school leaving certificate for professional qualifications.

\section{Characteristics of school placement}

Only a part of the school transfer phenomenon can be captured by using the survey method: the movement of pupils who live within the town that is being studied and of 
those who live elsewhere but go to school in that town. Nevertheless, the survey provides a means for understanding the educational strategies of "those who stay" (i.e. those who choose to stay or who cannot leave). The aim of the survey was to get a sense of what kind of school and educational future parents have in mind for their children when they make these "choices" regarding their schooling. Are these choices based on where the families live and how mobile their children can be? Or are they based instead on the different educational options that are available? How are these two dimensions integrated? The place where families live can thus be seen as only one factor that enters into the choice over schooling. But it can also be seen as the initial and fundamental factor that determines educational practice itself.

Practically all of the school transfers within Levallois are to private schools. The survey shows that it is mostly the privileged families, those who possess the greatest economic and cultural capital (managers, professionals, entrepreneurs, artisans), who transfer their children to schools outside their district, even though other social categories also do it. A closer look at transfer procedures shows that the transfers to private schools, which essentially concern the wealthy families of Levallois, are in line with a very classical approach to schooling. This approach is linked to the traditional practices of the Catholic bourgeoisie, which developed its own schooling circuits in a socio-spatial system that is old and well known: the beaux quartiers [Pinçon \& Pinçon-Charlot, 1988]. But there are also different kinds of school transfers, to other public schools, for example, which concern families who possess cultural capital, but may lack economic capital (intermediary professions and employees).

So, in Levallois, pupils who transfer out of the public school of their district are in general those who possess the most economic and cultural capital, or, more precisely, those with families whose distribution of capital is best adapted to the context in which they evolve. In contrast, families who possess cultural (but less economic) capital tend to prefer educational strategies within the public education sector. This is mainly because the private schools in the Levallois-Neuilly zone have adapted their education offer to the demands/needs - and relative level of affluence - of pupils who live in Levallois but do not attend the public school of their district. 
Parents who are blue-collar workers or unemployed are likely to have greater difficulty schooling their children outside their district, as their social and professional status is an important discriminatory factor in school transfers, and the most disadvantaged families may even find themselves to be captive of their districts. However, one could put forward the hypothesis that for these families, the fact that they live in Levallois already represents a form of 'social promotion', as they have access to better schooling conditions here than they would have if they lived in a less affluent community. In the survey, these families indicate that they are very satisfied with the school in their district (collège Danton or the collège Jaures) and see no reason to transfer their children to another school. As a parent of a pupil in a public college of Levallois said: "We're quite privileged in Levallois, compared to other towns like Clichy. The school has a very good reputation and the children do well in school. We're far removed from the ZEP (zones d'education prioritaire) and from negative things people say."

Most of the children who attend a school in Levallois other than the one officially attributed to them in their district live in Levallois. Yet, about one-third of the school transfers in Levallois concern children who live in neighbouring towns. The reputation of the schools in Levallois and, in particular, of its private college is quite far-reaching, attracting students from as far away as Saint-Denis. Several factors can explain this: pupils who transfer to schools outside of their districts often have greater mobility (i.e. $70 \%$ in a private car) than those who go to school in their district; moreover, Levallois is easily accessible by public transport.

Among the transfer students who live in Levallois there is an over-representation of artisans, shopkeepers and managers, but among the transfer students who come from neighbouring towns there is an over-representation of managers and intermediate professions. A comparison of the social profile of the inhabitants of Levallois with that of the children schooled in Levallois shows that there is a polarisation of the most privileged social categories to the detriment of middle class and disadvantaged social categories. While artisans, shopkeepers, entrepreneurs and upper-level managers and professionals represented $5 \%$ and $35 \%$ respectively of Levallois' active population in 1999, they represented $14 \%$ and $38 \%$ of the school-going population, even when taking into 
consideration the 'flight' of the most affluent among these (entrepreneurs and high-level professionals) to Neuilly schools.

This greater social polarisation of the educational space in comparison to the residential space is due in large part to the transfer of children to private schools. However, it is also necessary to analyse in greater detail the schooling practices of each social category. A first examination of survey results concerning the choice for schools makes it possible to better understand what drives the placement of children in the schools of the three towns being studied (Levallois, Clichy, Neuilly). With regard to the criteria used for selecting a school (see Table D), survey results show that the reputation of the school and of its teachers is more important for the parents of pupils in Levallois and in Neuilly than for those in Clichy, who pay more attention to purely educational criteria (availability of options, importance of $6^{\text {th }}$ grade test results, the school-leaving certificate offered by the collège, etc.). These differences become even more pronounced when the pupils are school transfers (see Table E). Matters such as student timetables, class size and the prospects of further education are not yet discriminatory factors for student placement at the collège entry level - especially since the schools in the towns examined here offer courses of study and sections with sufficient flexibility and variety so that access is not a major problem at this point.

As for obtaining information about the different schools, in Clichy more attention is given to teachers than in Neuilly, with Levallois taking an intermediate position (see Table D). The inverse is true for recommendations from friends and lists ranking schools by quality, which are given more importance in Neuilly than in Clichy (with Levallois as middle position). However, survey results should be differentiated here according to whether families are transferring their children or not, and according to their social category. Those who have transferred their children out of the school in their district tend to be more concerned by the options (than by the material conditions) that the other school can offer. These families also tend to depend much more on the advice of friends than families who have not transferred their children, and are more involved in school life. In the public school sector, families of student transfers are active mostly in parentteacher associations, while in the private sector the parent involvement focuses more on pedagogical issues. This no doubt depends on how available parents are to get involved 
in school life and on the quality of the education offer (making a battle over resources unnecessary); a lack of opportunity for pedagogical action in the public sector may also play a role.

The social significance of the differences in educational choices can be analysed here thanks to the reasons given in survey responses by students who have transferred out of their district (see Tables E and F). More than $80 \%$ of the pupils who live in Levallois, but go to school in Neuilly, cite reasons such as "gaining access to a better environment", "improving the chances of success for the student" and "fostering the development of the child". These reasons were considered to be less important by student transfers who go to school in Levallois, regardless of where they live. What matters to them is not so much educational criteria centred on the pupil, but much more criteria focusing on the reputation of the school and the quality of the education and learning conditions it can offer. The importance of "personal" criteria, related to concerns of "belonging", appears clearly in the responses provided by "transplants" who come from more modest family backgrounds, and who feel "out of place" in their school. An interview conducted with a student who goes to school in Neuilly but lives in Asnières reveals how difficult integration can be in schools in Levallois and Neuilly:

"They judge the students without knowing them. I remember an art teacher who criticised students wearing "tracksuits" - they were friends of mine - she made a remark about people living out in the "banlieue", and so forth. In Asnierès there were students like that, but the teachers didn't make those kinds of judgements (...) I had to pretend that I lived with my grandmother. They were on to me and I had to be very careful. If ever I had the misfortune of giving out my address in Asnierès... All the students who came from the banlieue were rated according to the way they looked, talked..."

(Former student in Asnierès, schooled in Levallois and then in Neuilly)

Finally, the responses given by transferred students in Levallois indicate that transferring to another school should not be seen so much as a flight from schools considered to have a working class enrolment, but instead as a means to access learning conditions that are better adapted to their expectations and lifestyles. This is reflected in the students' cultural practices and activities (see table $\mathrm{H}$ ). More than a third of the students have taken up an artistic activity (mostly music, but also theatre and the fine arts), and almost $10 \%$ pursue another extra curricular activity, such as practicing foreign languages, scouting or catechism. With regard to cultural outings, these families regularly attend shows and concerts. Their children practice mostly individual sports and, on a 
smaller scale, "elitist" sports such as riding, golf and mountain climbing (fewer than $6 \%$ belong to a football team). We have noted that neither the sports nor the artistic activities indicate differentiation with regard to social category, except for golf, riding and music, which are over-represented among transferred students. Indeed, these "elitist" (and expensive) activities are pursued essentially by social categories possessing the greatest economic capital (entrepreneurs) and cultural capital (upper-level managers and professionals). On the whole, such extracurricular activities highlight the objective link between privileged social class and school transfers, as going to the theatre, practicing foreign languages and scouting are practically the monopoly of students who have transferred out of the public school in their district. While these practices reveal a differentiation in the rapport to culture due to social category, they also indicate a desire on the part of the most privileged social categories to preserve a certain exclusiveness in their relatively closed educational circuits: in this context, the different practices of school placement and transfers have the function of social selection. 
Table D: Evaluation criteria for schools in percent (responses from all survey participants)

\begin{tabular}{|l|c|c|c|c|}
\cline { 2 - 5 } \multicolumn{1}{c|}{} & Clichy & Levallois & Neuilly & Total \\
\hline Timetable/schedule & $32 \%$ & $29 \%$ & $25 \%$ & $28 \%$ \\
\hline Options & $41 \%$ & $37 \%$ & $32 \%$ & $35 \%$ \\
\hline Tracking & $37 \%$ & $30 \%$ & $24 \%$ & $29 \%$ \\
\hline Material resources & $41 \%$ & $37 \%$ & $30 \%$ & $34 \%$ \\
\hline Class size & $29 \%$ & $33 \%$ & $26 \%$ & $28 \%$ \\
\hline $\begin{array}{l}\text { Reputation of the school } \\
\begin{array}{l}\text { Reputation of the } \\
\text { teachers }\end{array}\end{array}$ & $66 \%$ & $75 \%$ & $76 \%$ & $74 \%$ \\
\hline Test results (Grade 6) & $33 \%$ & $68 \%$ & $72 \%$ & $68 \%$ \\
\hline $\begin{array}{l}\text { School-leaving certificate } \\
\text { results }\end{array}$ & $37 \%$ & $34 \%$ & $27 \%$ & $31 \%$ \\
\hline Future prospects & $50 \%$ & $50 \%$ & $57 \%$ & $54 \%$ \\
\hline
\end{tabular}

Table E: Evaluation criteria used by families who transfer their children to other schools

\begin{tabular}{|l|c|c|c|c|}
\cline { 2 - 5 } \multicolumn{1}{c|}{} & Clichy & Levallois & Neuilly & Total \\
\hline Timetable/schedule & $40 \%$ & $27 \%$ & $27 \%$ & $27 \%$ \\
\hline Options & $50 \%$ & $42 \%$ & $28 \%$ & $32 \%$ \\
\hline Tracking & $10 \%$ & $30 \%$ & $21 \%$ & $23 \%$ \\
\hline Material resources & $50 \%$ & $28 \%$ & $26 \%$ & $27 \%$ \\
\hline Class size & $20 \%$ & $26 \%$ & $19 \%$ & $21 \%$ \\
\hline Reputation of the school & $70 \%$ & $75 \%$ & $79 \%$ & $78 \%$ \\
\hline $\begin{array}{l}\text { Reputation of the } \\
\text { teachers }\end{array}$ & $50 \%$ & $65 \%$ & $73 \%$ & $71 \%$ \\
\hline Test results (Grade 6) & $30 \%$ & $15 \%$ & $14 \%$ & $14 \%$ \\
\hline $\begin{array}{l}\text { School-leaving œrtificate } \\
\text { results }\end{array}$ & $30 \%$ & $26 \%$ & $25 \%$ & $25 \%$ \\
\hline Future prospects & $60 \%$ & $46 \%$ & $52 \%$ & $51 \%$ \\
\hline
\end{tabular}

Table F: Criteria for transferring schools (cited by families who transfer their child ren to other schools)

\begin{tabular}{|l|c|c|c|c|}
\cline { 2 - 5 } \multicolumn{1}{c|}{} & Clichy & Levallois & Neuilly & Total \\
\hline Proximity to home & $40 \%$ & $28 \%$ & $25 \%$ & $26 \%$ \\
\hline Proximity to work & $20 \%$ & $8 \%$ & $6 \%$ & $7 \%$ \\
\hline Accessibility & $10 \%$ & $6 \%$ & $11 \%$ & $9 \%$ \\
\hline Leaming environment & $60 \%$ & $81 \%$ & $85 \%$ & $84 \%$ \\
\hline Achievement level & $40 \%$ & $78 \%$ & $82 \%$ & $80 \%$ \\
\hline Student development & $60 \%$ & $73 \%$ & $77 \%$ & $76 \%$ \\
\hline Under-achievement & $10 \%$ & $8 \%$ & $2 \%$ & $4 \%$ \\
\hline Siblings & $50 \%$ & $24 \%$ & $28 \%$ & $27 \%$ \\
\hline Religious affiliation & $10 \%$ & $38 \%$ & $49 \%$ & $45 \%$ \\
\hline Better school & $20 \%$ & $24 \%$ & $29 \%$ & $27 \%$ \\
\hline Special options & $10 \%$ & $14 \%$ & $12 \%$ & $12 \%$ \\
\hline
\end{tabular}


Table G: Obtaining information about schools (methods used by families who transfer their children to other schools)

\begin{tabular}{|l|r|c|c|c|}
\cline { 2 - 5 } \multicolumn{1}{l|}{} & \multicolumn{1}{|c|}{ Clichy } & Levallois & Neuilly & Total \\
\hline Recommended by friends & $30 \%$ & $51 \%$ & $56 \%$ & $54 \%$ \\
\hline Recommended by teachers & $40 \%$ & $28 \%$ & $18 \%$ & $21 \%$ \\
\hline $\begin{array}{l}\text { School attended by a family } \\
\text { member }\end{array}$ & $50 \%$ & $32 \%$ & $39 \%$ & $38 \%$ \\
\hline Lists ranking schools by quality & $0 \%$ & $8 \%$ & $19 \%$ & $16 \%$ \\
\hline
\end{tabular}

Table H: Cultural practices by town and school transfer

\begin{tabular}{|c|c|c|c|c|c|c|c|c|}
\hline & \multicolumn{4}{|c|}{ Cultural activities by transfer students } & \multicolumn{4}{|c|}{$\begin{array}{c}\text { Cultural activities by non- } \\
\text { transfer students }\end{array}$} \\
\hline & Clichy & Levallois & Neuilly & Total & Clichy & Levallois & Neuilly & Total \\
\hline No sports & $50 \%$ & $38 \%$ & $21 \%$ & $26 \%$ & $44 \%$ & $39 \%$ & $27 \%$ & $36 \%$ \\
\hline Individual sports & $0 \%$ & $17 \%$ & $22 \%$ & $20 \%$ & $11 \%$ & $11 \%$ & $15 \%$ & $14 \%$ \\
\hline Popular sports & $40 \%$ & $39 \%$ & $43 \%$ & $42 \%$ & $28 \%$ & $40 \%$ & $44 \%$ & $37 \%$ \\
\hline Team sports & $10 \%$ & $5 \%$ & $3 \%$ & $4 \%$ & $8 \%$ & $5 \%$ & $3 \%$ & $6 \%$ \\
\hline Elitist sports & $0 \%$ & $1 \%$ & $11 \%$ & $9 \%$ & $5 \%$ & $4 \%$ & $11 \%$ & $7 \%$ \\
\hline No artistic activity & $70 \%$ & $51 \%$ & $54 \%$ & $53 \%$ & $85 \%$ & $74 \%$ & $58 \%$ & $72 \%$ \\
\hline Dance & $10 \%$ & $6 \%$ & $8 \%$ & $8 \%$ & $3 \%$ & $8 \%$ & $14 \%$ & $9 \%$ \\
\hline Music & $10 \%$ & $25 \%$ & $21 \%$ & $22 \%$ & $6 \%$ & $8 \%$ & $17 \%$ & $11 \%$ \\
\hline Theatre & $0 \%$ & $9 \%$ & $9 \%$ & $9 \%$ & $3 \%$ & $5 \%$ & $5 \%$ & $4 \%$ \\
\hline Several & $10 \%$ & $10 \%$ & $8 \%$ & $8 \%$ & $3 \%$ & $6 \%$ & $6 \%$ & $5 \%$ \\
\hline No cultural outings & $50 \%$ & $44 \%$ & $54 \%$ & $52 \%$ & $53 \%$ & $54 \%$ & $55 \%$ & $54 \%$ \\
\hline Regular cultural outings & $30 \%$ & $15 \%$ & $11 \%$ & $12 \%$ & $41 \%$ & $26 \%$ & $17 \%$ & $28 \%$ \\
\hline Thatre / opera & $20 \%$ & $40 \%$ & $35 \%$ & $36 \%$ & $6 \%$ & $19 \%$ & $28 \%$ & $18 \%$ \\
\hline Does not watch TV & $30 \%$ & $31 \%$ & $37 \%$ & $35 \%$ & $23 \%$ & $24 \%$ & $20 \%$ & $22 \%$ \\
\hline $\begin{array}{l}\text { Entertainment } \\
\text { programmes }\end{array}$ & $10 \%$ & $13 \%$ & $4 \%$ & $7 \%$ & $14 \%$ & $16 \%$ & $11 \%$ & $13 \%$ \\
\hline Films and serials & $30 \%$ & $17 \%$ & $9 \%$ & $12 \%$ & $16 \%$ & $20 \%$ & $12 \%$ & $15 \%$ \\
\hline $\begin{array}{l}\text { Programmes for } \\
\text { children }\end{array}$ & $10 \%$ & $10 \%$ & $14 \%$ & $13 \%$ & $15 \%$ & $12 \%$ & $14 \%$ & $14 \%$ \\
\hline $\begin{array}{l}\text { Educational } \\
\text { programmes }\end{array}$ & $10 \%$ & $10 \%$ & $7 \%$ & $7 \%$ & $8 \%$ & $8 \%$ & $5 \%$ & $6 \%$ \\
\hline
\end{tabular}




\section{Different circuits of schooling}

We analysed the various correspondences and similarities of the survey responses that we collected in Clichy, Levallois and Neuilly, using a standard Multiple Correspondence Analysis [LE RouX \& ROUANET, 2004]. The results of the analysis highlight three main axes, tracing the distribution of individuals and the divides in educational and cultural practices that characterise them (see figure 1$)^{4}$.

The first of these axes (27\% of total inertia) contrasts clearly a set of social and educational factors, revealing the existence of a very definite social hierarchy between the towns and the schools of the towns. The students enrolled in the public collegès in Clichy are contrasted with those attending the private colleges in Neuilly, with those in public schools in Levallois being situated in-between these two poles. This opposition between the places where the students attend school manifests itself also at the level of educational characteristics and achievement: of the three towns studied, Clichy is the one where the students lag behind, having attended only the public school in their district, while in Neuilly there is an over-representation of students who are above or at achievement level, having families firmly established in the community, or coming from families who live in affluent neighbouring towns. This contrast can also be seen very distinctly with regard to social category, with the children in Clichy coming principally from working class and underprivileged family backgrounds (employees, blue-collar workers, unemployed, with limited education ${ }^{5}$ ), and those in Neuilly having parents who are high-level managers and professionals, with at least 5 years of higher education. This hierarchy of social characteristics is also reflected in cultural practices. On the one hand there is a variety of extracurricular activities (theatre, dance, fine arts, catechism, individual sports, e.g. riding, golf) - and an educational use of television, and on the other hand, there are few cultural activities or outings, more team sports, and a use of television and new technologies focused on entertainment.

These social contrasts manifest themselves also at the educational level. Transfer students attend mainly private schools in Neuilly, or private and public schools in Neuilly

\footnotetext{
${ }^{4}$ For further details about the construction of variables of this standard MCA, see [FRANÇOIs \& POUPEAU, 2005].

${ }^{5}$ With regard to mothers, they tend to be employees, working in the service sector, in particular providing services to people, such as caretakers.
} 
and Levallois, while students who do not transfer and remain in the public school of their district are enrolled in the colleges of Clichy, which is an indication of very distinct educational circuits. While families in the first group are more concerned by the reputation of the school and future educational opportunities it can offer, the other families tend to focus more on the material conditions in the school (resources, equipment, class size) and strictly educational criteria (class level, examination results). These oppositions can be seen in a cloud of individuals where, along axes 1 and 2 , transfer and non-transfer students stand out very clearly ${ }^{6}$.

Along axes 2 and 3, however, the differences in characteristics are less distinct, and are less defined by social polarisation in the place of residence and in the schools. Along axes 1 and 3, the cloud does not show points that are very different, but it has a form that denotes a Gutman effect, expressing an increased hierarchy of space, which was already present along axis 1 . We will thus pay particular attention to axes 2 and 3 here, in order to point out significant differences.

Axis $2(15 \%$ of the inertia) contrasts public and private colleges in the same town, Neuilly, and two different groups of students. On the one hand, there are pupils who are performing above level, living in Neuilly and attending the public school in their district without ever having gone to private school (although they may have requested a transfer). On the other, there are pupils performing below level, attending private school, whose families have lived for more than 16 years in Neuilly or in a neighbouring town, such as Puteaux, Suresnes or Clichy. This opposition is also very much marked by both socioprofessional and educational factors: while the pupils attending public schools in Neuilly come from families with a strong educational background (upper-level managers), those attending private schools there come from families with less education (employees, blue-collar workers, intermediate professions). Upon close examination of cultural and educational practices, one can see that axis 2 shows not only a difference in schooling, but two different rapports with the school itself, depending on the amount of educational capital that the parents possess and can transmit within the family context.

\footnotetext{
${ }^{6}$ This hypothesis could be refined by verifying the extent of the clouds of points and by calculating the 'average points', as was done by Jean Chiche, Brigitte le Roux, Pascal Perrineau and Henry Rouanet in an article that has guided our interpretation here, in particular with regard to axes 2 and 3 ("L'espace politique
} 
As for cultural practices, the contrasts in this area are less evident than for educational practices (axis 1). There is an inversion between the social categories possessing much educational capital (enrolled in public school) and those possessing less (enrolled in private schools), almost completely inversing (without the residential factor) the oppositions that were noted previously. The families who have enrolled their children in private school in Neuilly seem preoccupied with the safety of the school environment and the strict supervision of pupils (e.g. class timetable), which is not incompatible with their concern over educational quality, and they strongly reject the public school in their district, considering it to be a bad school. They seem to use very diversified sources to gain knowledge about schools, such as personal acquaintances, school advisors, lists ranking school quality, etc. On the other hand, parents who enrol their children in public school in Neuilly base their choice of school much more on learning conditions (class size, class level, examination results, reputation of teachers) and seem to have better inside knowledge of how the education system functions. This is probably because being well educated, they have spent more time making their way through the education system and thus are more familiar with it, which is apparent in their involvement in parentteacher associations (in particular, in the most conservative one).

The third axis (13.3\% of inertia) reveals a different kind of polarisation. It contrasts students attending public collèges in Levallois with those attending private collèges in Neuilly. The first group has the following characteristics: the students perform at level in school, and live in working-class towns near Levallois; they have no siblings and have never transferred schools before Grade 6, or they attend the same school as their siblings; their parents have obtained the baccalaureate (education level IV), and work in intermediary professions; these students express an active interest in culture, and attend different cultural events, including the theatre; they participate in team sports, go scouting and dancing; however, contrary to the other groups of students, they also show great interest in television programmes, video games and the Internet. When it comes to choosing a school, these families take all criteria (except for hours of school presence) into consideration, but their attachment to the public school of their district is evident in

des électeurs français à la fin des années 1990. Nouveaux et anciens clivages, hétérogénéité des electorates", Revue française de science politique, vol.50, n³, 2000, p.463-487). 
that they do not seek information about other schools. Furthermore, the parents themselves were schooled in the public sector, with the mothers having attended rather prestigious schools.

When looking at axes 2 and 3, one can thus distinguish groups that have very different rapports to schooling. First, between the public and the private education sector, but also within each sector. For example, the public schools in Levallois are distinct from those in Neuilly, which have more educational capital, but the public schools in both towns are different from the private schools, which are very much split between students belonging to the local traditional bourgeoisie and external transfer students, who come from affluent surrounding towns, as well as Clichy, and whose economic capital makes it possible to pay the private school fees. So, there seem to be three circuits of schooling that are very distinct from each other: a "school for the people" (public schools in Clichy); a "school for the gentrified middle classes" (public schools in Levallois and Neuilly, depending on means); and a "school for the traditional bourgeoisie" (private schools in Neuilly, enrolling pupils from both Neuilly and surrounding towns). From a statistical point of view, one can note a relative correspondence between the characteristics of the schools and the distribution of the economic and cultural capital of the families.

From the point of view of school transfers, students who perform above level, and who come from families with the most economic and cultural capital, tend to go to school in Neuilly (51 students from Levallois, of which almost 40 have parents who are professionals). In this group, students who are most likely to attend private schools have parents who are high-level managers and, above all, artisans, shopkeepers and entrepreneurs, even if in the end the latter are under-represented in the private school sector, considering how many of them are settled in Neuilly. In this regard, one can make the hypothesis that for these professions, living in Neuilly is a more important strategy than going to school in Neuilly. On the other hand, students who transfer schools within the public sector (either locally or to another town) tend to come from families working in intermediate professions or as employees. If, in Neuilly, it is mostly managers who transfer their children out of their district's school, in Levallois it is essentially professionals and managers who do it. In Clichy, the few families who send their children 
to schools outside their district (mostly to Levallois and occasionally to Paris) tend to work in intermediary professions.

While axes 1 and 2 respectively reveal the importance of the global volume of capital possessed by families and of the structure of economic and cultural capital distribution, axis 3 expresses more the impact of the local situation, a type of "mobility capital", linked to the possibilities of gaining access to the local education offer, either through where families live or what resources they can mobilise to avoid sending their children to the assigned school in their district. One can make the hypothesis here that the "choice of schooling" made by parents is based on their capacity to make the right move [sens du placement], which is the product of incorporating all their living conditions local housing opportunities, access to cultural life, mobility, schools. When it involves those public services, the parents who possess the greatest economical and cultural capital are aware that these can be avoided by turning to the private sector, provided that they have the means.

The hypothesis of a sense of making the right move is necessary here for understanding the aptitude of individual families to find circuits of schooling that are adapted to their specific social position and means (in particular to the structure of economic and cultural capital distribution), and also for understanding how these families relate to other families, operating in the same competitive space. Their economic and cultural capital can be used more or less, depending on the local characteristics of the education offer that is accessible to them: in this regard, the spatial dimension has a significant impact on school placement practices in that it can ensure a greater or smaller return on family capital. If we are to refine the indicators and variables that are used to comprehend what drives social categories into socially and spatially distinct circuits of schooling, then we should start by analysing the structure of economic and cultural capital distribution. 


\section{References}

-BALL S., BOWE R; \& GEWIRTZ S., 1995, «Circuits of schooling: A sociological exploration of parental choice of school in social class contexts », Sociological Review, p.53-78.

-BALliON R., 1986, «Les familles et le choix du collège ", L'orientation scolaire et professionnelle, $\mathrm{n}^{\circ} 15$ (3), p.183-202.

-BOURDIEU P., La distinction, Paris, Minuit, 1982 ; La Noblesse d'Etat, Paris, Minuit, 1989.

-Broccolichi S. ET VAN ZANTEN A., 1997, «Espaces de concurrence et circuits de scolarisation. L'évitement des collèges publics dans un district de la banlieue parisienne $»$, Annales de la recherché urbaine, $\mathrm{n}^{\circ} 75$ (16), p.5-31.

-FrANÇOIS J.-C., 2002, «Evitement à l'entrée en $6^{\text {ème }}$ et division sociale de l'espace scolaire à Paris », L 'espace géographique, ${ }^{\circ} 4$, p. 307-327.

-FRANÇOIS J.-C.\& POUPEAU F., 2005, La mixité sociale à l'école. De l'espace résidentiel à l'espace scolaire, rapport au ministère de l'Éducation nationale.

-Le Roux B. \& Rouanet H., 2004, Geometric Data Analysis. From Correspondence Analysis to Structural Data Analysis, Dordrecht/Boston/London, Kluwer Academic Publishers.

-MERLLIE D., 1990, «Les classements professionnels dans les enquêtes de mobilité », Annales, 44(6), p. 1317-34.

-PInÇON M. \& PINÇON-CHARLOT M., 1999, Dans les Beaux Quartiers, Paris, Seuil. 